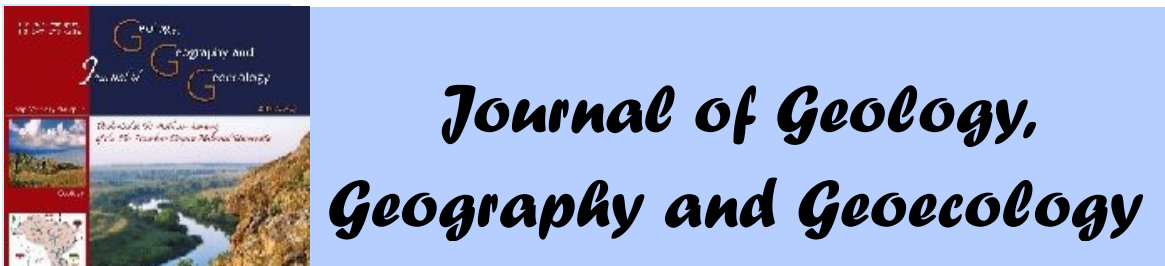

Journal home page: geology-dnu-dp.ua
ISSN 2617-2909 (print)

ISSN 2617-2119 (online)

Journ.Geol.Geograph.

Geoecology,

27(2), 337-345

doi: $10.15421 / 111858$

O. I. Shablii, L. B. Zastavetska,

K. D. Dudarchuk, I. D. Illiash, N. M. Smochko

Journ.Geol.Geograph.Geoecology, 27(2), 337-345

\title{
The main problems of healthcare and wellness tourism in Ukraine
}

\author{
O. I. Shablii ${ }^{1}$, L. B. Zastavetska ${ }^{2}$, K. D. Dudarchuk ${ }^{2}$, I. D. Illiash ${ }^{3}$, N. M. Smochko ${ }^{4}$ \\ ${ }^{1}$ Lviv National Ivan Franko University, Lviv, Ukraine, e-mail:kafedra.lviv@gmail.com \\ ${ }^{2}$ Ternopil National Pedagogical University named after Volodymyr Hnatyuk, Ternopil,Ukraine, e- \\ mail:zast.lesia@gmail.com \\ ${ }^{3}$ Ternopil National Economic University, TernopilUkraine, e-mail:irailliash@gmail.com \\ ${ }^{4}$ Mukachevo State University, Mukachevo,Ukraine, e-mail:natazak@ukr.net
}

\author{
Received17.07.2018; \\ Received in revised form 29.07.2018; \\ Accepted 03.08.2018
}

\begin{abstract}
The data of the conducted research testify to the high potential of Ukraine, taking into account factors such as favourable climate, location near two seas and rich natural resources for healthcare and wellness tourism. Significant weaknesses have been identified, which consist of an outdated infrastructure of healthcare and wellness enterprises and the narrow range of services provided by them. Only $67 \%$ of the total number
\end{abstract} of establishments of the sanatorium and resort complex have service departments inside, but even if they are available, most of the health-improvement facilities according to the requirements of the National Standard for Accommodation do not even correspond to category 1 . In the course of the conducted research, methods of statistical analysis were applied to study the dynamics of the number of sanatoria and health facilities in Ukraine and the number of tourists. Methods for diagnosing the state of development and modeling (including SWOT analysis, cluster approach) were used to study the functioning of tourist territories of different taxonomic ranks. It was found on the basis of study that although Ukraine has all the resources for the development of healthcare tourism, it is still a depressed industry owing to numerous problems. The materials of this research can become a practical basis for the development of this kind of tourism. The main problems of development of tourist infrastructure of healthcare tourism are described. The directions of its development are proposed: construction of new hotels, recreation centers, shelters, hotels, camping sites, etc. and reconstruction of available accommodation facilities. It was found that a similar situation is observed in the places of public catering (their significant insufficiency negatively affects the development of this sphere of tourism ). It is proposed to create an innovative cluster of health-improving type on mono-territories, which will allow the best possible social and economic development projects to be designed and implemented, as well as helping to effectively build and implement a strategy for long-term development of the territory, which has favourable conditions for sanatorium and resort treatment.

Key words: healthcare and wellness tourism, sanatorium and resort business, spa business, sanatoria-resort cluster.

\section{оловні проблеми розвитку лікув льно-оздоровчого туризму в кр їні}

$$
\text { . . блій }{ }^{1}, \text {. . ст вецьк }{ }^{2}, \text {. . уд рчук }{ }^{2}, \text {. лляш }{ }^{3}, \text {. } \text { мочко }^{4}
$$

I ввівський н ціон льний університет імені вн $в$ н нк, ввів, кр їн, kafedra.lviv@gmail.com

2 ернопільський н ціон льний пед гогічний університет імені олодимир н тюк, ернопіль, кр їн, e-mail:zast.lesia@gmail.com

3 ернопільський н ціон льний економічний університет, ернопіль, кр їн, e-mail: irailliash@gmail.com ук чівський держ вний університет, ук чево, кр їн,e-mail:natazak@ukr.net

нот ція. ні проведеного дослідження свідч ть про високий потенці л кр їни, з огляду н т кі чинники як сприятливий клім т, розт шув ння поблизу двох морів, б г ті природні ресурси, які доцільно м ксим льно використовув ти в лікув льно-оздоровчому н прямку туризму. иявлено зн чні сл бкі сторони, які поляг ють в з ст рілій інфр структурі лікув льнооздоровчих підприємств і вузький сортимент н д в них ними послуг. $з$ з г льної кількості з кл дів с н торно-курортного комплексу підрозділи сфери сервісу м ють тільки $67 \%$ уст нов, проте н віть 3 н явності т ких, більшість оздоровчих 3 кл дів згідно вимог ціон льного ст нд рту до з собів розміщув ння не відповід ють н віть к тегорії $1 . \quad$ ході проведеного дослідження для вивчення дин міки кількості с н торно-оздоровчих з кл дів в кр їні, кількості рекре нтів були з стосов ні методи ст тистичного н лізу. ля вивчення ст ну функціонув ння туристичних територій різних т ксономіч- 
них р нгів використовуються методи ді гностув ння ст ну їх розвитку т моделюв ння (у тому числі SWOT- н ліз, кл стерний підхід). иявлено н підст ві дослідження, що хоч кр їн м є всі ресурси для розвитку оздоровчого туризму, це депресивн г лузь через н явність численних проблем. тері ли дослідження можуть ст ти пр ктичною основою для розвитку т кого виду туризму. х р ктеризов но основні проблеми розвитку туристичної інфр структури оздоровчого туризму. пропонов но н прями їі розвитку: будівництво нових готелів, 6 з відпочинку, притулків, готелів, створення кемпінгів і т.д. і реконструкція н явних об'єктів розміщення. иявлено, що н логічн ситу ція спостеріг ється і в пл ні місць гром дського х рчув ння (суттєв їх недост тність нег тивно вплив є н розвиток д ної сфери туристичної діяльності). пропонов но створення іннов ційного кл стер лікув льно-оздоровчого типу н монотериторіях, що дозволить н йкр щим чином спроектув ти можливості соці льно-економічного розвитку, т кож ефективно вибудув ти і ре лізув ти стр тегію довгострокового розвитку території, як м є сприятливі умови для с н торно-курортного лікув ння.

лючові слов : оздоровчий туризм, с н торно-курортний бізнес,

-бізнес, кл стер лікув льно-оздоровчого типу.

Introduction. Healthcare and wellness tourism tourism is one of the types of tourist and recreational activities, which involves traveling to the regions with the most favourable natural conditions, including climate for health, , for the prevention, treatment or rehabilitation of disease. It is one of the most stable types of tourist markets and priority areas in Ukraine. However, itis greatly in need of support and coordinated development. Available and potential reserves of treatment resources, taking into account of their qualitative and quantitative characteristics, should now become the stimulus for public practice in human health restoration, extending the active period of life and introducing of a healthy lifestyle, all of which determines the relevance and subject matter of this article.

Ukraine has a fortunate combination of diverse and rich natural resources, thatcan be used to preserve and improve the health of the population, extending life expectancy: a favourable climate and range of ecological zones, forest, forest-steppe and steppe, mountainous and coastal areas, a unique microclimate of salt mines, a wide range of natural mineral waters, therapeutic mud, ozokerite, etc.

Material and methods of research: The methods of statistical analysis were used in order to study the dynamics of the number of sanatoria and health institutions in Ukraine and the number of tourists. To study the functioning of tourist territories of

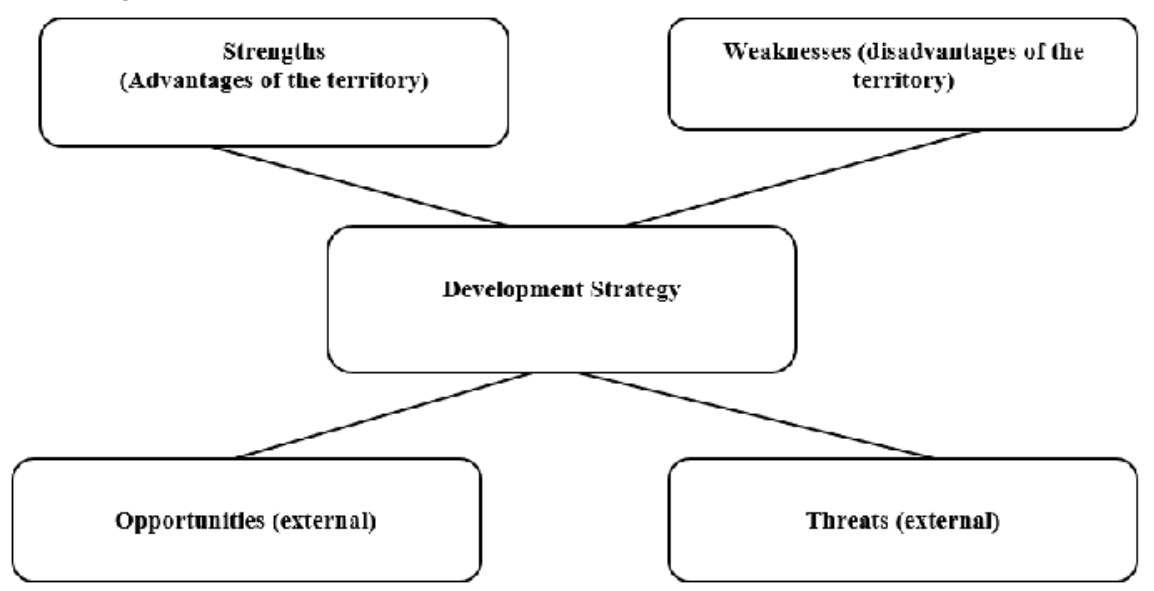

Fig. 1. Components of the SWOT analysis of the territory different taxonomic ranks, methods of diagnosing the state of their development and modeling are used. Methods of diagnosing the state of the tourist and recreational system are systematic procedures for describing the system and its components with the use of qualitative and quantitative parameters.

A clear reflection of the status of tourist systems are models (including clusters), which conditionally represent the image of the object which is in a certain accordance with the system.

In recent years, for the study of many phenomena of social life, the SWOT analysis (in the translation of the word - strength, weakness, opportunities, threats) has been applied more widely, which involves studying the "strategy of behaviour" of the objects under the influence of four groups of factors (the advantages of the territory, favourable factors of the environment, deficiencies of the territory, counteraction to the external environment). The practical result of the SWOTanalysis should be the corresponding table showing the strategic directions of the development of tourist objects or regions (Fig. 1).

The continuation of this method is the socalled TOWS-analysis, which involves forecasting of changes in these objects due to changes in the environment (Table 1). Thus the focus is on the construction of four groups of different strategies , each of which uses one of the pair combinations (Kolodii, Sprynskyi, 2005).

\section{Threats (externaI)}


Such methods can be supplemented by other expert ones, but the main role in forecasting the development of tourist areas is played by factorial methods. They include methods of analysis of dy- namics, spatial interaction, taxonomic grouping (classification), optimization of development (Lebedieva, 2011).

Table 1.The matrix of TOWS-form

\begin{tabular}{|l|l|l|}
\hline & \multicolumn{1}{|c|}{ O (Opportunities) } & \multicolumn{1}{c|}{ T (Threats) } \\
\hline $\begin{array}{l}\text { S } \\
\text { (Strengths) }\end{array}$ & $\begin{array}{l}\text { SO (success strategy) } \\
\text { «Maxi-Maxi» strategies } \\
\text { strategies of using strengths to use the opportunities provided }\end{array}$ & $\begin{array}{l}\text { ST (conservation strategy) } \\
\text { «Maxi-Mini» strategies } \\
\text { strategies of using strengths to minimize } \\
\text { threats }\end{array}$ \\
\hline W (Weaknesses) & $\begin{array}{l}\text { WO (competition strategy) } \\
\text { «Mini-Maxi»strategies } \\
\text { strategies to minimize weaknesses through the use of opportuni- } \\
\text { ties provided }\end{array}$ & $\begin{array}{l}\text { WT (defense strategy) } \\
\text { «Mini- Mini»strategies } \\
\text { strategies for minimizing weaknesses and } \\
\text { threats }\end{array}$ \\
\hline
\end{tabular}

Results and their analysi. In our time, health tourism is one of the main components of the tourism industry, especially for inhabitants of economically developed countries, where influential factors are the consequences of transport development, its active promotion, pollution of the environment due to industrial development, etc. A healthy lifestyle means that many people are looking for health and relaxation in other, environmentally friendly regions. Health tourism is based on the use of natural resources: mineral water, therapeutic mud and climatic conditions, which in combination with each other positively affect the treatment of various diseases.

The development of healthcare and wellness tourism is closely linked to the state of the sanatorium and spa industry, and Ukraine's current conditions it faces certain difficulties. The number of spa complexes and resorts is reduced, there is lack of funding, physical deterioration of medical equipment, etc. But despite this, Ukraine has rich recreational tourism potential and important prerequisites for the creation of highly developed tourist facilities.

The political instability in the country and deep financial and economic crisis have led to an increase in the cost of services with poor quality of service, which is the reason for the decline in demand and the reduction in the occupancy of sanatoriums, which is today at about $40 \%$ capacity.

Another problem that the research suggests is that there is now a real threat to the national security of Ukraine due to low birth rates, high morbidity and mortality.

The most important criteria that characterize the health of the population are:

1) the frequency of newly established cases of disease per year;

2) prevalence of the disease (ie, all cases of the disease detected during the year, including the first detected and chronic cases that had existed before).

According to the State Statistics Committee, the general level of incidence per 100 thousand of the population in the period 1995-2017 in Ukraine has increased by $58.4 \%$, and in 2017 there were 67,998 episodes of morbidity compared to 42,947 cases in 1995. The number of registered cases for the first time remains practically the same (Table 2). By comparison - the level of morbidity in European countries is approximately 40,000 cases per 100 thousand of population (The Law of Ukraine "On Resorts", 2000).

Table 2. The morbidity dynamics of the population of Ukraine

\begin{tabular}{|c|c|c|}
\hline Years & $\begin{array}{c}\text { Number of cases of disease per 100 thousand of } \\
\text { population, persons }\end{array}$ & The number of first-time cases of disease, persons \\
\hline 1995 & 42,937 & 32,547 \\
\hline 2000 & 59,439 & 33,471 \\
\hline 2005 & 81,916 & 32,912 \\
\hline 2010 & 78,148 & 33,080 \\
\hline 2015 & 68,558 & 26,881 \\
\hline 2017 & 67,998 & 26,789 \\
\hline
\end{tabular}


Given the above-mentioned problems, the organization of effective rest, health and recreation, prevention and reduction of morbidity and disability, as well as the health promotion of the population of all age groups are of particular importance during a period of challenging socio-economic and environ-mental conditions (Lebedieva, 2011).

The climatic resorts of the Southern coast of Crimea, the balneological resorts of the PreCarpathian and Transcarpathian regions, Podillya, Poltava, the mud-resorts of Crimea and Odessa region are well-known since ancient times. The first institutions that used mineral water for treatment began func-tioning in Shklo (1576), Saky (1799), Truskavets (1827), Odessa (1829), Berezovske (1862), Morshyn (1877); the healing properties of the mud - on the shores of the Liman Kuyalnyk (1833), and near Gola Prystan' (1895).

Table 3. Sanatorium and health resorts

\begin{tabular}{|c|c|c|c|c|c|c|c|c|c|c|}
\hline \multirow{2}{*}{ Years } & $\begin{array}{c}\text { Sanatoria and board- } \\
\text { ing houses with } \\
\text { treatment }\end{array}$ & \multicolumn{2}{|c|}{$\begin{array}{c}\text { Sanatoria-preventive } \\
\text { clinics }\end{array}$} & \multicolumn{2}{|c|}{$\begin{array}{c}\text { Holiday homes and } \\
\text { pensions }\end{array}$} & \multicolumn{2}{|c|}{$\begin{array}{c}\text { Bases and other } \\
\text { recreation facilities }\end{array}$} & \multicolumn{2}{|c|}{$\begin{array}{c}\text { Children's health } \\
\text { camps }\end{array}$} \\
\cline { 2 - 11 } & Total & $\begin{array}{c}\text { Number of } \\
\text { beds, ths }\end{array}$ & Total & $\begin{array}{c}\text { Number } \\
\text { of beds, } \\
\text { ths }\end{array}$ & Total & $\begin{array}{c}\text { Number } \\
\text { of beds, } \\
\text { ths }\end{array}$ & \multicolumn{2}{|c|}{ Total } & $\begin{array}{c}\text { Number } \\
\text { of beds, } \\
\text { ths }\end{array}$ & $\begin{array}{c}\text { Total } \\
\text { Number beds, } \\
\text { ths }\end{array}$ \\
\hline 2010 & 510 & 141 & 234 & 19 & 290 & 60 & 1920 & 217 & 17342 & 196 \\
\hline 2011 & 508 & 141 & 224 & 19 & 280 & 59 & 1947 & 216 & 17703 & 194 \\
\hline 2012 & 484 & 133 & 185 & 18 & 286 & 60 & 1925 & 208 & 17744 & 188 \\
\hline 2013 & 477 & 132 & 165 & 15 & 271 & 57 & 1916 & 202 & 18549 & 191 \\
\hline 2014 & 320 & 79 & 118 & 17 & 90 & 17 & 1400 & 157 & 13977 & 126 \\
\hline 2015 & 309 & 78 & 79 & 12 & 76 & 15 & 1399 & 165 & 9743 & 113 \\
\hline 2016 & 291 & 70 & 63 & 10 & 73 & 14 & 1295 & 146 & 9669 & 112 \\
\hline 2017 & 290 & 70 & 63 & 10 & 72 & 14 & 1295 & 146 & 2968 & 111 \\
\hline
\end{tabular}

As Figure 2 shows, over the past 5 years, the number of health resort users has also significantly decreased. This fact can be explained by an increase in prices for services rendered in health facilities.

During the years of independence, the sanato-rium and resort sector in Ukraine has practically re-mained without state subsidies. The lack of budget financing was a consequence of a reduction in a number of state programmes (sanatorium and resort treatment of patients with tuberculosis, traumatic diseases of the spinal cord, cardiac patients, etc.).
In recent decades, there has been a tendency towards a decrease in the number of sanatorium and wellness establishments (see Table 3), which is due to a number of problems that exist in the country (socio-economic, military operations in the east, occupation of the territory of the Autonomous Republic of Crimea, etc.)

By 2017, the number of health-improvement institutions of all types had decreased by almost 2 times compared with 2010 . This is especially true for children's recreation camps (decreased from 17.3 thousand institutions to 9.6 thousand ), sanatoria and boarding houses with treatment (decreased from 510 institutions in 2010 to 290 in 2017), as well as sanatoria-preventive clinics (234 establishments in 2010 compared to 63 in 2017). This is due to the fact that a huge number of them was concentrated in the Crimea. Ukraine has lost these health facilities because the occupation of this territory. 


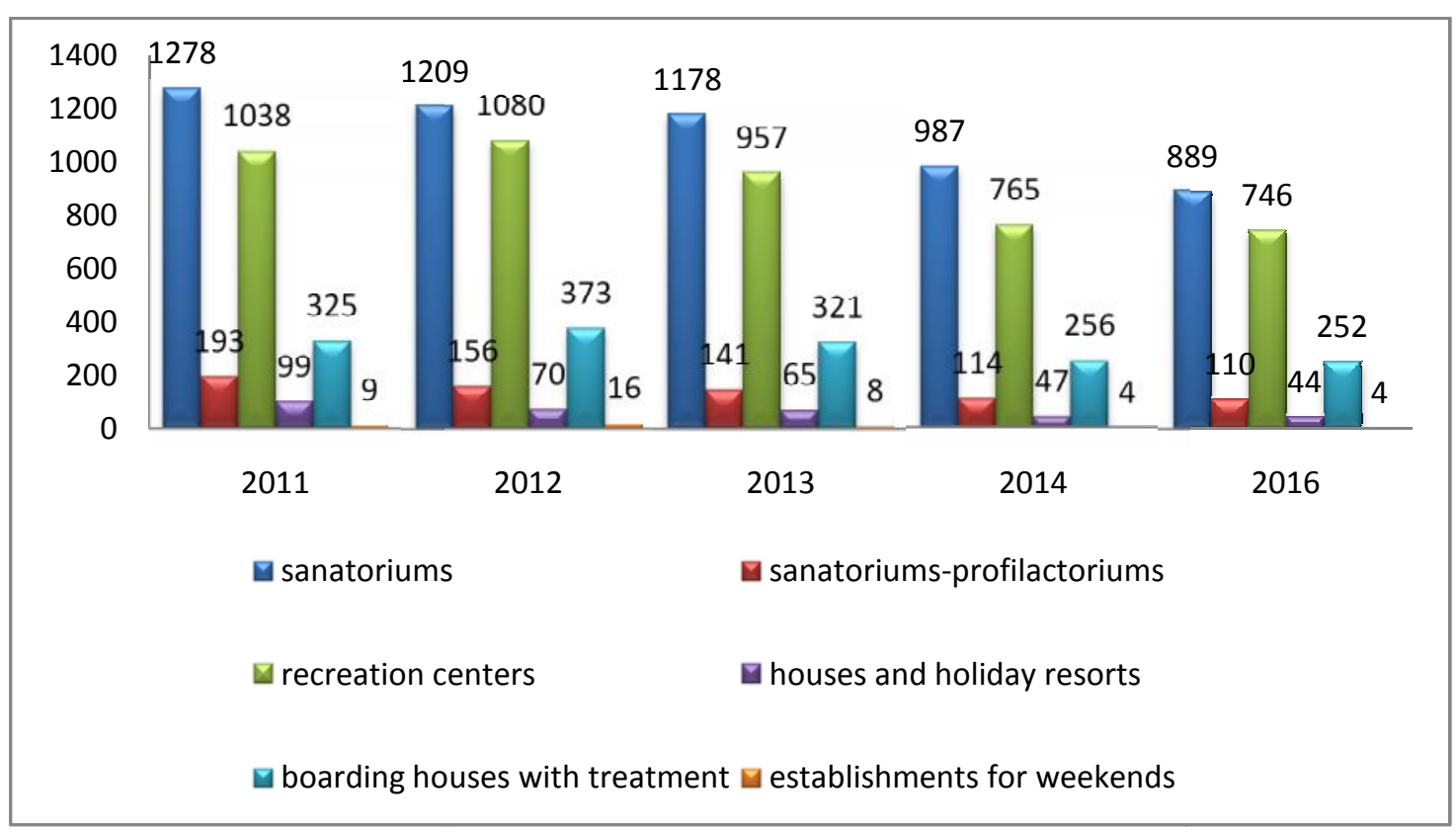

Fig. 2. Number of persons who have been to establishments within the sanatorium and resort complex, thousands of people

The sanatorium-resort sector is regulated by the Law of Ukraine "About Resorts", the current regulatory framework which regulates its functioning, the economical and rational use of natural therapeutic resources and their protection, declare that of sanatorium and health treatment should be accessible for citizens of all age groups, first of all, for the disabled, veterans of war and labour, combatants, citizens affected by the Chernobyl accident, TB patients, children and women of reproductive age (Zapototskyi, 2013). However, the imperfection of the system of legislative regulation is a significant obstacle to the year-round operation of the sanatorium and resort complex: in budgets of all levels, donations in the health system are neither foreseen nor equated to industrial enterprises after tax payment. Such conditions lead to a rise in the cost of sanatorium and resort services, reduce the possibility of loading health establishments, and, therefore, cause a number of socio-economic losses (Zapototskyi, 2013).

The development of healthcare and wellness tourism is directly related to the rational use of natural therapeutic resources in the territories dedicated to health-improvment. However, a significant number of health-improving institutions consume deposits of natural therapeutic resources with unconfirmed and invaluable reserves. Most of the exploited mineral water wells are technically and technologically obsolete and are usually used for industrial bottling in plastic containers. In this case, packaged mineral water is not used in accordance with medical zoning in other health facilities and in hospitals. The State inventories of natural medicinal resources and natural territories of resorts was created in Ukraine in order to compare the effectiveness of the recreational and non-recreational use of the resorts, the medical-biological assessment of the quality of natural therapeutic resources, the ecological and economic assessment of the natural areas of the resorts and the formation of the market for natural therapeutic resources and the introduction of a system of paid nature use.

The state inventory of natural areas of resorts is an effective instrument for monitoring, rational current and future use of natural areas of resorts in accordance with approved urban planning documentation for sanatorium treatment, medical rehabilitation, tourism and recreation development; ensuring effective collection, processing, preservation and analysis of information on the state of the environment and natural therapeutic and recreational resources in the territories of the resorts and forecasting their changes under the influence of economic activity; effective environmental protection measures and the development of scientifically substantiated recommendations on the use of natural ar-

eas of resorts.

Establishment of priority directions of the use of natural medical resources, improvement of the cultural-historical heritage, and protection and enrichment of the natural environment require the balance between interdisciplinary interests regarding the placement of resort, residential and social considerations, engineering, transport, communal and other objects. Thus, the development of the infrastructure of the territories of resorts and healthimprovement areas requires the solution of complex territorial problems. At the same time, industrial 
zones pose a real threat to the deposits of mineral waters, mud and other natural medical resources. Intensification of economic activity, proximity of trunk roads with the low level of service, high prices, and imperfect infrastructure undermine the reputation of health facilities.

The development of healthcare and wellness tourism depends to a large extent on prices for fuel and energy resources, since they directly affect the cost of permits. Thus, the intensification of the introduction of energy-saving technologies, reproducible and non-traditional energy sources, which is an effective instrument for maintaining a sustainable ecological situation and the subject of state policy, promotes the minimization of the energy dependence of health establishments.

Sustainable development of healthcare and wellness tourism is impossible without modernization of water management, water treatment and sewage facilities; exploration and mobilization of underground water for drinking water supply and rational use of available sources. At present, the state priority is the construction of closed water supply systems for health facilities, regardless of their ownership and subordination, as part of the strategy of promoting non-waste technologies (Zapototskyi, 2013). It is worth emphasizing the diverse subordination of health-improving institutions. Sanatoria, boarding houses, houses and recreation facilities operate in different departments: professional trades union systems, the Ministry of Health, the Ministry of Internal Affairs, the Ministry of Transport, the State Department of Affairs, the Ministry of Industrial Policy, Fuel and Energy, etc. There are also institutions that are on the balance of large enterprises and associations. However, studies have shown that the crisis of the sanatorium and resort complex, is largely due to the lack of funds for the maintenance of health resorts in departments, on whose balance sheets they are fixed (Zaporoshchenko, 2017).

In addition to these problems, the development of healthcare and wellness tourism has the characteristic features of a crisis situation: the lack of effective economic mechanisms of functioning with a low level of service; the practical absence of internal and external investments at a high level of depreciation of fixed assets; unsystematic development of health facilities with ineffective managerial and marketing strategies, practices, methods and methods at macro, meso and micro levels.

Researchers emphasize that the strategies of development of resorts of state and local impor- tance should take into account the introduction of an efficient system of financing the sanatorium and resort industry and the creation of a system for encouraging of investments in modernization and construction of sanatorium and resort industries, creating affordable health products, adherence to state standard treatment methods and medical rehabilitation at resorts, and coordination of activities of sanatorium and health resorts, regardless of the form of ownership and subordination.

Application. Analysis of the development of the strengths and weaknesses of the state of healthcare and wellness tourism in Ukraine is presented in Table 4.

The data presented in Table 4 shows the high potential of Ukraine, taking into account factors such as favourable climate, location near two seas, rich natural resources that are expedient to use as much as possible in the health and wellness tourism sector. There are significant weaknesses that lie in the outdated infrastructure of the healthcare facilities and the narrow range of services provided by them. Only $67 \%$ of the total number of facilities in the sanatorium and resort complex have service sector units, but even if they are available, most health-improving facilities do not even correspond to category 1 in accordance with the requirements of the National Standard.

At the same time, a holiday home, a pension, a health facility of 1-2 days of stay does not have any service area. It is necessary to emphasize separately the continuous non-compliance with the general requirements for taking into account the needs of the disabled and other low mobile groups of the population.

Opportunities are represented by a tendency towards investing public funds in the development of health-improving tourism and its infrastructure, in connection with the creation of clusters in the country, which will lead to the formation of a specific mono specialization in order to expand the interconnections within the recreational and tourist system, which imposes a significant imprint on trade, free movement of capital, human and information resources.

Despite the rapid development of information technology over the last decade, giving great possibilities for operative information exchange between companies, the territorial feature of the cluster does not lose its relevance today, as the special significance in the cluster association has regular informal connections, which are possible only in conditions of territorial proximity. 
Table 4. SWOT-analysis of the state of healthcare and wellness tourism in Ukraine

\begin{tabular}{|c|c|}
\hline Strengths & Weaknesses \\
\hline $\begin{array}{l}\text { - favourable climatic conditions of most of Ukraine, which can } \\
\text { be widely used for climatology treatment of recreation; } \\
\text { - geographic location, the country's exit to two seas - the Black } \\
\text { and Azov, contributes to the development of resort and beach } \\
\text { recreation in the recreational programs; } \\
\text { - the presence of several natural deposits of medicinal mud, } \\
\text { many deposits of mineral waters of different chemical composi- } \\
\text { tion; } \\
\text { - the presence of such unique objects as the Carpathian Bios- } \\
\text { phere Reserve, the nature reserves "Synevir", "Medobory", } \\
\text { "Dniester Canyon", etc., attracting visitors to tourists who are } \\
\text { staying in health institutions; } \\
\text { - border location of many health and recreation centers, which } \\
\text { contributes to the development of inbound health and wellness } \\
\text { tourism (Zakarpattia region, Odessa region); } \\
\text { - availability of developed logistics transport corridors and } \\
\text { rather well-developed port infrastructure; } \\
\text { - existence of infrastructure for supporting small and medium } \\
\text { enterprises }\end{array}$ & $\begin{array}{l}\text {-healthcare and wellness tourism activity has a pronounced } \\
\text { seasonality; } \\
\text { - outdated material and technical base of many medical and } \\
\text { recreational enterprises of the country; } \\
\text { - inconsistency of the price and quality of providing health- } \\
\text { improving tourist services; } \\
\text { - insufficient use in the recreation of available natural thera- } \\
\text { peutic resources in the country; } \\
\text { - a narrow range of proposed healthcare and treatment services } \\
\text { by enterprises; } \\
\text { - a narrow range of additional leisure services at healthcare and } \\
\text { wellness enterprises; } \\
\text { - insufficient promotion and branding of the regions of } \\
\text { Ukraine as favourable for medical and health tourism; } \\
\text { - absence of a unified policy of hospitality in the field of pro- } \\
\text { viding wellness and healthcare services; } \\
\text { - high cost of transport services; } \\
\text { - the absence of developed complexes of road infrastructure. }\end{array}$ \\
\hline & \\
\hline $\begin{array}{l}\text { - attraction of state investments in the development of health- } \\
\text { care and wellness tourism in the country; } \\
\text { - the possibility of forming interregional health tourism } \\
\text { projects; } \\
\text { - the possibility of forming time tourist and recreational centers } \\
\text { at the expense of industrial clusters }\end{array}$ & $\begin{array}{l}\text { - low level of development of specialized infrastructure and } \\
\text { service of healthcare and wellness sphere of tourism, including } \\
\text { hotels, public catering establishments, passenger transport; } \\
\text { - unsatisfactory condition of tourist facilities, which are used in } \\
\text { leisure activities as part of recreational rest of tourists; } \\
\text { - the natural and climatic characteristics of individual regions } \\
\text { (the Carpathian region, the Black Sea and the Sea of Azov) } \\
\text { dictate the seasonal component and the unevenness of the } \\
\text { provision of certain types of therapeutic and health services }\end{array}$ \\
\hline
\end{tabular}

A characteristic feature of a recreation-tourist cluster with healthcare and wellness mono specialization is not only the complementarity of the enterprises that belong to it but also the impossibility of their functioning outside the recreational and tourist sphere. Since territorial recreational systems include regional systems and functional networks (separate sectors of the recreational economy for their particular placement), the establishment of a stable network of horizontal links among its elements is the basis for the formation of specialized objects of space - cluster formations on the mono territories of tourist and recreational type.

Clusters can be located at the territory of one or several regions, and represent a special monospace - a special type of territory.

We note that in most cases special-type territories become associated into mono-specialized clusters, a cluster being considered by the authors as a certain group of interrelated companies, specialized suppliers of services, firms in the corresponding branches, infrastructure, research institutions, universities and other organizations (which are complementary and enhance the competitive advantages of each other and the cluster in general), which is concentrated in a territory characterized by a pronounced monospecialization. At the same time, in subsequent years, clusters become not only spontaneously organized groups of enterprises and organizations, but also a purposeful and quite effective instrument of state economic policy.

In particular, this form of organization in a number of countries has been used as the main instrument of the new economic policy (UK, PRC, Finland, USA, etc.), and in some cases also in the form of an anti-crisis strategy (Canada).

Formation of cluster recreational and tourist formations should be based on the objective competitive advantages of a mono-tier, taking into account their possible changes in the future, which undoubtedly requires not only the availability of natural prerequisites for the development of recreation and tourism, but also significant efforts in the formation of a favourable infrastructure (see Fig. 3).

The influx of tourists requires the presence of tourist infrastructure: the construction of new hotels, recreation centers, shelters, hotels, camping, etc. and reconstruction of available accommodation facilities. A similar situation is observed in terms of places of catering. 


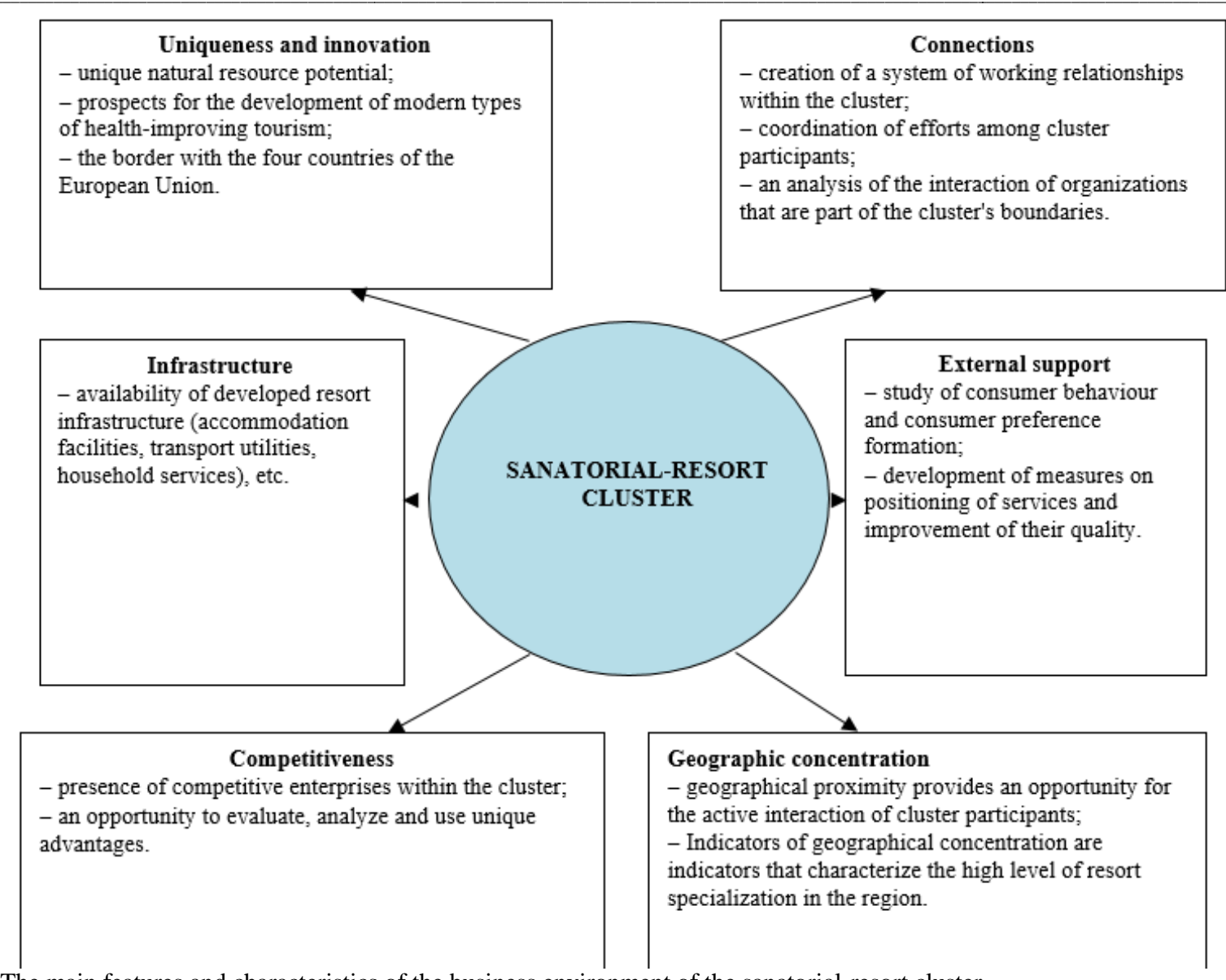

Fig. 3. The main features and characteristics of the business environment of the sanatorial-resort cluster

Creation of an innovative cluster of healthimproving type on mono-territories will provide the best way to design opportunities for socioeconomic development, as well as to effectively build and implement a strategy for long-term development of this territory.

The center of the healthcare and wellness cluster may be several powerful institutions of the sanatorium and resort area, engaged in the production and promotion of tourist products of the region, which help each other, that is, position the cluster. The territorial situation may range from one to two major tourist monospecialized points (or centers) within villages, cities / hubs, districts, zones within the region / country and even several neighboring countries (cross-border clusters), which often leads to a synergistic effect.

Clusters by their existence prove the effectiveness of public-private partnership in achieving the goal of sustainable tourism development within a region, providing quality tourism services, stimulating demand and maintaining its proper level, providing local people with jobs.

Conclusions. The current market situation reveals the weak and strong sides of the Ukrainian resorts, formed in the above-mentioned historical conditions. For example, the strengths or competitive advantages are: the availability of treatment for a wide range of people; medical specialization and purpose of sanatorium-resort establishments, powerful scientific potential; weaknesses are: the weakened factor of "historical uniqueness" in the brands of some domestic resorts compared with foreign ones; in fact, the absence of well-known domestic brands in the sanatorium and resort industry, with the exception of several resort associations; low level of service and diversification of services; low profitability due to "hereditary" low prices.

In order to eliminate the mentioned negative factors of development of the sanatorium and resort complex it is expedient to:

1) implement social policy in order to further increase the level and quality of life of the population;

2) improve the efficiency of the general state and regional regulation of the sanatorium and resort sphere;

3) develop and implement a complex of measures aimed at attracting investments for the development of the infrastructure of the sanatorium and resort complex;

4) improve the system of publicising the possibilities of the healthcare and wellness industry of the country as a whole, to position Ukraine on the 
world market of healthcare and wellness services as a major region of treatment and rehabilitation;

5) develop the information and advertising and marketing activities of sanatorium and resort establishments; balance the price policy and quality of the basic and additional healthcare and wellness services, introduce a system of discounts;

6) improve the organization of the activities of sanatorium and spa establishments, aimed at reducing the cost of their maintenance and reducing the cost of travel vouchers;

7) pay more attention to the development and implementation of innovative measures for the offer of individualization at the resort and the formation of new domestic brands in the market of sanatorium and resort services of Ukraine by the enterprises of the healthcare and wellness industry;

8) staffing of the healthcare and wellness establishments with qualified specialists.

\section{References}

Honhalo P.F., 2004. Problemy vidtvorennia resursnoho kompleksu Ukrainy [Problems of reproduction of the resource complex of Ukraine]. Economics and ecology. 15. 125-127 (in Ukrainian).

Zakon Ukrainy «Pro kurorty» (№2026-III vid 05.10.2000 r.) [The Law of Ukraine "On Resorts" (No. 2026-III dated October 5, 2000)] Retrieved fromhttp://www.kmu.gov.ua.

Zaporoshchenko A. S., 2017.Statystychna otsinka rivnia zakhvoriuvanosti ta yakosti medychnoho obsluhovuvannia naselennia Ukrainy[Statistical estimation of the morbidity and quality of medical care of the population of Ukraine]. Statistics a tool for socio-economic research. 3. 77 81(inUkrainian).

Zapototskyi $\quad$ S.P., $2013 . \quad$ Rehionalna konkurentospromozhnist yak stratehichnyi napriam suchasnoi rehionalnoi polityky [Regional competitiveness as a strategic direction of modern regional policy]. Economic and social geography. 79-86(inUkrainian).

Informatsiinyi potral dlia profesion aliv farmatsevtychnoi ta medychnoi sfery Ukrainy ta inshykh krain. [Informational portal for professionals in the pharmaceutical and medical sectors of Ukraine and other countries] Retrieved fromhttp://medpharmconnect.com/Ukrainian_mar ket/Ukrainian_Healthcare.

Kolodii V.V., Sprynskyi M.I., 2005. Mineralni vody karpatskoi provintsii [Mineral waters of the Carpathian province]. Problems of mineral waters. 458 (inUkrainian).

Kontseptsiia rozvytku sanatorno-kurortnoi haluzi, skhvalena rozporiadzhenniam Kabinetu Ministriv Ukrainy № 231-r. vid 23.04.2003 r. [The concept of the development of the sanatorium and resort industry, approved by the Cabinet of Ministers of Ukraine No. 231-p. of 23.04.2003] / Retrieved fromhttp://www.kmu.gov.ua

Lebedieva V.V., 2011. Stratehiia rozvytku pidpryiemstv sanatorno-kurortnoho kompleksu [Strategy of development of enterprises of sanatorium and resort complex]: dys... kand. ekon. nauk: 08.00.04.167(inUkrainian).

Postanova KMU vid 26 lypnia 2001 r. №872 «Pro zatverdzhennia Poriadku stvorennia i vedennia Derzhavnoho kadastru pryrodnykh likuvalnykh resursiv» [Resolution of the Cabinet of Ministers of Ukraine of July 26, 2001, No. 872 "On Approval of the Procedure for the Establishment and Maintenance of the State Cadastre of Natural Medicinal Resources"] Retrievedfromhttp://zakon4.rada.gov.ua (inUkrainian).

Postanova KMU vid 23 travnia 2001 r. №562 «Pro zatverdzhennia Poriadku stvorennia i vedennia Derzhavnoho kadastru pryrodnykh terytorii kurortiv» [Resolution of the Cabinet of Ministers of Ukraine of May 23, 2001 N522 "On Approval of the Procedure for the Establishment and Maintenance of the State Cadastre of Natural Resorts of Resorts"] Retrieved fromhttp://zakon4.rada.gov.ua (inUkrainian).

Savosta O., 2008.Efektyvnist derzhavnoho upravlinnia [Effectiveness of public administration]. 16/17. 365-371(inUkrainian).

Posluhy turystychni. Klasyfikatsiia hoteliv: DSTU 4269:2003. - [Chynnyi vid 2003-12-23]. K.: Derzhspozhyvstandart Ukrainy. 17 (inUkrainian).

Shablii O. I., 2003.Osnovy zahalnoi suspilnoi heohrafii [Fundamentals of general social geography]. Lviv: Vyd. tsentr LNU. 444 (inUkrainian). 